\title{
Using an Autologous Fibrin Sealant in the Preventing of Cerebrospinal Fluid Leak with Large Skull Base Defect Following Endoscopic Endonasal Transsphenoidal Surgery
}

\author{
Endoskopik Endonazal Transsfenoidal Cerrabi Sırasında Oluşan Geniş \\ Kafa Tabanı Defektine Bă̆lı Beyin Omurilik Sıvısı Kaçă̆ı Tamirinde \\ Otolog Fibrin Yapuștırıcı Kullanım
}

Ali Erdem YILDIRIM ${ }^{1}$, Engin DURSUN ${ }^{2}$, Cagatay OZDOL ${ }^{3}$, Denizhan DIVANLIOGLU ${ }^{1}$,

Osman Arikan NACAR ${ }^{1}$, Oguz KARAKOYUN ${ }^{1}$, Adil ERYILMAZ ${ }^{4}$, Ahmed Deniz BELEN ${ }^{1}$

${ }^{1}$ Ankara Numune Research and Education Hospital, Department of Neurosurgery, Ankara, Turkey

${ }^{2}$ Recep Tayyip Erdogan University, Faculty of Medicine, ENT, Rize, Turkey

${ }^{3}$ Antalya Numune Research and Education Hospital, Department of Neurosurgery, Antalya, Turkey

${ }_{4}^{4}$ Ankara Numune Research and Education Hospital, ENT, Ankara, Turkey

Corresponding Author: Ali Erdem YILDIRIM / E-mail: alierdemyildirim@gmail.com

\begin{abstract}
AIM: Postoperative cerebrospinal fluid (CSF) leak following endoscopic endonasal transsphenoidal surgery (EETS) is associated with increased morbidity and mortality. This prospective study is the first evaluation of using autologous fibrin sealant for preventing postoperative CSF leak and related complications.

MATERIAL and METHODS: 200 endoscopic endonasal transsphenoidal approaches were included in the study and reviewed retrospectively from September 2010 to June 2012. A total of 55 patients who have large skull base and diafragma sella defects, connected with basal cisterns or ventricles, were chosen for the study. The patients were operated via extended or classical endoscopic endonasal transsphenoidal approach. The skull base has been repaired using AFS combined with multilayer reconstruction in all cases. The incidence of CSF leak as a complication of EETS was analyzed.

RESULTS: The ages of the patients ranged from 20 to 83 years (mean 49.3 years). There were 25 (46\%) male patients and 30 (54\%) females. All patients had tumors with suprasellar or parasellar extension. Postoperative CSF leak was determined in 2 patients (3.6\%). There were no complications and allergic reactions associated with the use of AFS.

CONCLUSION: Using of AFS combined with multilayer reconstruction technique is a safe and effective method to prevent CSF leak in large defects following EETS.
\end{abstract}

KEYWORDS: Endoscopic endonasal transsphenoidal, Cerebrospinal fluid leak, Autologous fibrin sealant, Skull base reconstruction

öz

AMAÇ: Endoskopik endonazal trassfenoidal cerrahi (EETC) sonrasında gelişen postoperatif beyin omurilik sıvısı (BOS) kaçağı bu prosedürün morbidite ve mortalitesini arttıran bir faktördür. Bu prospektif çalışma postoperatif BOS kaçağının ve buna bağlı komplikasyonların engellenmesi amacıyla otolog fibrin yapıştırıcı kullanımının ilk örneğidir.

YÖNTEM ve GEREÇLER: Ekim 2010 ile Haziran 2012 arasında endoskopik endonazal transsfenoidal yaklaşım ile ameliyat edilen 200 olgu retrospektif olarak değerlendirildi ve çalışmaya dahil edildi. Bunlar arasından bazal sisternler veya ventriküller ile iliş̧isi olan geniş diafragma sella defekti veya geniş kafa tabanı defekti bulunan toplam 55 hasta seçildi. Hastalar genişletilmiş veya klasik endoskopik endonazal transsfenoidal yaklaşım ile opere edildi. Kafa tabanı tamiri tüm olgularda çok katmanlı tamir yöntemi ile otolog fibrin yapıştırıcı kullanılarak gerçekleştirildi. EETC'nin bir komplikasyonu olan BOS kaçağının insidansı analiz edildi.

BULGULAR: Hastaların yaş dağııımı 20 ile 83 (ortalama 49.3) arasında idi. Bunlardan 25’i (\%46) erkek, 30'u (\%54) kadındı. Tüm hastalarda suprasellar veya parasellar uzanım gösteren tümör bulunmaktaydı. İki hastada (\%3.6) postoperatif BOS kaçağı saptandı. Otolog fibrin yapıştırıcıya bağlı herhangi bir komplikasyon veya allerjik reaksiyona rastlanmadı.

SONUÇ: Çok katmanlı tamir ile birlikte otolog fibrin yapıştıcı kullanımının, EETC sonrası gelişebilecek BOS kaçağının engellenmesinde güvenli ve etkin bir teknik olduğunu düşünmekteyiz.

ANAHTAR SÖZCÜKLER: Endoskopik endonazal transsfenoidal, Beyin omurilik sıvısı kaçağı, Otolog fibrin yapıştırıcı, Kafa tabanı tamiri 


\section{INTRODUCTION}

Endoscopic endonasal transsphenoidal surgery (EETS) is generally considered a safe and effective technique for removal of pituitary adenomas and many other parasellar tumors $(4,13)$. Surgical repair of skull base defects during the EETS procedure is an important and necessary step to prevent postoperative complications, and to provide anatomic integrity (23). The most common serious potential complication of EETS is cerebrospinal fluid (CSF) leakage that could result in disasterous intracranial complications such as meningitis or pneumocephalus $(28,33)$. A history of previous surgery or radiation exposure, obesity, a large duramater defect, opening of cisterns or ventricles during the surgery, a large volume of tumor resection, leaving a residual tumor and incompliance of the patient during the postoperative period are factors that may increase the risk of postoperative CSF leakage (33). The postoperative CSF leakage incidence of EETS is $2.3 \%-6.4 \%$ and has been reported to increase (mean $10 \%)$ after extended approaches $(6,28,33)$.

Various techniques and materials depending on surgeons' experiences are used for skull base reconstruction to prevent CSF leak $(4,9,13,17,28,33,37,40)$. Intradural and/ or extradural closure of skull base defect and packing of the sella with or without packing of the sphenoid sinus can be the technical options (37). The majority of surgeouns use a combination of autologous intra-dural grafts (fat, muscle, fascia lata, dermal grafts, lyophilised dura mater), a hemostatic agent (collagen sponge, oxidized cellulose, etc.) and/or some form of rigid/semi-rigid buttressing (nasal septum, sphenoid bone, titanium mesh, biodegradable plates or Foley catheter). Usage of vascularized mucosal flaps, dural substitutes and tissue sealants have also been described $(1,4,5,9,10,12$, $13,15,16,17,18,19,21,22,23,27,28,29,33,34,36,37,39$, $40,41)$. Even primary suturing of the dural defects has been reported (31). These can be deployed either with or without the assistance of lumbar CSF diversion $(6,13,35,37,38)$.

Fibrin sealants are frequently used in skull base reconstruction. Using an autologous fibrin sealant (AFS) is a new procedure. Although AFS is preferred mostly in urological, pulmonary and cardiothoracic surgeries, there is no previous data in the literature about usage in skull base reconstruction $(2,14,24$, 32). Thus, this study is the first evaluation of using an AFS for the prevention of CSF leakage following EETS for large skull base and diaphragma sellae defects.

\section{MATERIAL and METHODS}

A total of 55 patients who underwent endoscopic endonasal transsphenoidal surgery among 200 endoscopic endonasal transsphenoidal approaches between September 2010 and June 2012 at the Ankara Numune Research and Education Hospital, Department of Neurosurgery were included in the study and reviewed retrospectively.

All of the included patients had similar selection criteria, preoperative evaluation, surgical technique and post-operative management. Preoperatively, all patients underwent clinical examination, endocrine testing, ophthalmological and rhinological assessment, and radiological investigations. MRI was chosen as the radiological investigation method due to its better tumor definition. Coronal and axial CT scanning without radiopaque enhancement was performed for preoperative evaluation of nasal cavity and paranasal sinuses. CT scan images were also useful to assess the pneumatization of the sphenoid and the position of its septa.

Among the patients operated on with the EETS approach, 46 had pituitary adenoma (83.7\%), 3 had craniopharyngioma (5.5\%), 2 had clivus chordoma (3.6\%), 1 had nasopharyngeal carcinoma with skull base invasion (1.8\%), 2 had olfactory groove meningioma (3.6\%), and 1 had tuberculum sella meningioma (1.8\%). Among the pituitary adenomas, 29 were non-secretory adenomas $(52.7 \%), 5$ were prolactinomas (9.1\%), 3 were corticotropinomas (5.5\%), and 9 were somatotropinomas (16.4\%). Among all 55 patients, a total of 6 were operated via an extended EETS approach (Table I).

Rigid endoscopes with $4 \mathrm{~mm}$ diameter and $180 \mathrm{~mm}$ length, and equipped with zero, 30 and 45 -degree lenses, according to different steps of the surgical operation were used. Thinner endoscopes in diameters of $2.7 \mathrm{~mm}$ can be used to ease access, especially in children and in patients with narrow nostrils.

All patients but 6 underwent classical endoscopic endonasal transsphenoidal surgery, using the paraseptal route $(4,37)$. The other patients were operated via the extended EETS approach. All procedures were performed with informed consent of the patients.

As a routine classical EETS procedure, mononostril approach without removal of the middle turbinate and posterior septectomy was often preferred. However, a binostril approach with either partial or total removal of the middle turbinate and posterior septectomy was performed in all of the extended EETS procedures. In the extended cases, excision of vomer and sphenoid sinus walls provides broad exposure of the skull base for four handed surgical assistance. In this approach, the planum sphenoidale, tuberculum sellae and superior and middle thirds of clivus could be removed according to the tumor invasion.

In all cases, multilayer reconstruction was performed for skull base defect using fat graft, fascia lata, absorbable hemostat (Surgicel ${ }^{\circ}$ fibrillar) and AFS (Vivostat", Vivostat A/S, Borupvang 2 DK-3450, Alleroed / Denmark). Fat tissue and/or fascia lata were obtained by nearly two-centimeter superolateral thigh incision as needed. The defects of the anterior skull base dura and diaphragma sellae were plugged snugly with fat tissue and/or fascia lata and later supported with absorbable hemostat and AFS. Dural defect in the sellar region was reconstructed with fascia lata graft both intradurally and extradurally (between the dura and the sellar base bone). The grafts were also supported with a layer of AFS. At the end, the rest of the AFS was applied as a thick layer over the reconstruction area till it completely obliterated the sphenoid 
Table I: Distrubition of the Patients Operated via EETS

\begin{tabular}{|c|c|c|c|c|c|c|}
\hline & Case Count & Percent (\%) & CSF Diversion & Rhinorrhea & Approach & Extended \\
\hline Pituitary Adenoma & 46 & 83,64 & 1 & 2 & EETS & \\
\hline Non-secretory & 29 & & & 2 & & \\
\hline Prolactinomas & 5 & & & & & \\
\hline Corticotropinomas & 3 & & 1 & & & \\
\hline Somatotropinomas & 9 & & & & & \\
\hline Craniopharyngioma & 3 & 5,45 & 1 & & $\mathrm{EETS}+\mathrm{TT}$ & 1 \\
\hline Clivus chordoma & 2 & 3,64 & & & $\mathrm{EETS}+\mathrm{TCl}$ & 2 \\
\hline Nasopharyngeal carcinoma & 1 & 1,82 & & & $\mathrm{EETS}+\mathrm{TCl}$ & \\
\hline Olfactory groove meningioma & 2 & 3,64 & 2 & & $\mathrm{EETS}+\mathrm{TCr}$ & 2 \\
\hline Tuberculum sella meningioma & 1 & 1,82 & 1 & & $\mathrm{EETS}+\mathrm{TT}$ & 1 \\
\hline Total Count & 55 & & 5 & 2 & & 6 \\
\hline
\end{tabular}

EETS: Endoscopic Endonasal Transsphenoidal, TT: Transtubercular, TCI: Transclival, TCr: Transcribriform

sinus. A foley catheter was inflated over the sphenoid sinus for preventing the dislodgement or prolapse of reconstruction materials due to gravity. Packing of the nasal cavity was not considered necessary, except in the case of diffuse intraoperative bleeding.

Lumbar CSF diversion was used in selected obese patients $(B M I \geq 30)$ and tumor cavity connected with the third ventricle or cisterns. External lumbar drainage (ELD) was used in 5 patients in the postoperative period (9.1\%). The withdrawal of drains was completed in the postoperative 5 days, and all of the patients were complication-free.

AFS was applied with the use of Vivostat ${ }^{\circ}$ System. The Vivostat ${ }^{\circ}$ System is a fully automated device formed by gathering of three components: an automated microprocessor control unit; an automated application unit and a disposable singlepatient-use unit. The fully automated microprocessor control unit is a nonsterile and reusable electromechanical device that drives and controls the biochemical process that takes place within the disposable preparation unit (Prep Unit) for preparing a concentrated fibrin solution from $120 \mathrm{ml}$ blood. Biotinbatroxobin is the initiator for the biochemical process, that acts upon the patients own plasma fibrinogen; the process depends entirely on endogenous thrombin of the patient own which produces a sealant that overcomes the potential infective and antigenic risk (25). The automated application unit is a nonsterile, reusable, microprocessorcontrolled electromechanical device, in which the fibrin and buffer cartridges are inserted. The unit then pushes forward those solutions into the application pen using a multi-lumen catheter. Solution application speed can be adjusted as low, medium or high. The last component is a disposable singlepatient-use unit by which AFS is prepared and applied. The unit includes a blood collecting set where patients own blood was collected and used for the biochemical process that produces the fibrin solution (26). This system prepares 5-6 ml of AFS from $120 \mathrm{ml}$ of the patient's own blood in about 30 minutes. The desired blood was obtained frequently from an arterial line if available. Otherwise a venous vascular access could be used. The fibrin sealant was applied with the use of the endoscopic applicator.

Postoperative discomfort was minimal and the narcotic analgesics were rarely necessary. Nasal drainage was also minimal. An ointment was also used with antibiotics for local applications in the nasal cavity three times a day. Patients were kept on antibiotics. Because of the risk of postoperative diabetes insipidus, the patients were observed regularly at their hospital room for five days. An endocrine evaluation was performed if necessary.

\section{RESULTS}

Fifty-five consecutive patients were recruited into the study. Their ages ranged from 20 to 83 years (mean 49.3). There were 25 (46\%) male and 30 (54\%) female patients. All of them had tumors with suprasellar and parasellar extension.

All of the 55 patients were followed up between 1 to 20 months (mean 10.3). Patients were hospitalized between 4 to 10 days (mean 5.2) after the operation. Patients were followed up with clinico-endoscopic assessment in postoperative $3^{\text {rd }}$ day and after one month. There was no complication (vascular or neural) among the 55 cases. Only 2 postoperative CSF leaks were determined (3.6\%), and both of them were reoperated and repaired successfully with the previously described method. There were also no complications and allergic reactions associated with the use of AFS.

No permanent Diabetes Insipidus (DI) was recorded in this study, but temporary Dl occurred in two cases. Onlyone patient developed hematoma, which absorbed spontaneously, on the removed fascia area on the leg. Postoperative pain was minimal and patients often did not require analgesic medications. There were no local or systemic infections recorded. 


\section{DISCUSSION}

EETS is an accepted approach in the treatment of sellar and parasellar pathologies. However, endoscopic repair of CSF leakage with skull base defect after surgery is still the major problem without any universal consensus $(28,33)$. This becomes a far more exaggerated trouble after a large skull base and diaphragma sella defect with a cistern or ventricle connection.

Probably this is not only due to the various reconstruction techniques but also because of the different equipment and materials that could be used for the repair. In fact, after an extended EETS surgery the defects tend to be larger and more complex than those following a standard pituitary surgery, so the reconstruction process and materials used for the repair always represent a challenge (33). Besides preventing CSF leak, skull base reconstruction is performed for reducing the dead space, creating a protective barrier, and preventing the descent of the chiasm into the sellar cavity (37). Our aim in this study is to discuss the results of 55 patients, who underwent EETS surgery for multilayer skull base reconstruction by using only autologous grafts. As is known, autologous grafts interact with the normal anatomical tissues, stimulating the migration of fibroblasts, and maintain to complete recovery of the anatomical barrier (30).

With respect to the previous trials about skull base reconstruction after EETS surgery, Kaptain et al. in 2001 performed reconstruction with fat, septal bone graft, and macrosorb in 10 patients. The patients were followed by postoperative external lumbar drainage and 1 patient (10\%) experienced CSF leakage (20). Couldwell et al. in 2004 used fat, fascia and lactosorb in their trial and observed CSF leakage in 2 patients (5.2\%) (8). In their study Dusick et al. performed a repair with fat, collagen sponge and titanium in 24 patients, and observed CSF leakage in 5 patients (20.8\%) (11). Finally, in 2007 de Cavallo et al. used lactosorb and dehydrated human pericardium (Tutoplast) in their trial, including 21 patients, where 2 patients (9.5\%) experienced CSF leakage (7). In our study, only 2 patients experienced postoperative rhinorrhea (3.6\%). We observed a hematoma, which was absorbed without any intervention, on thigh where fat and facia lata graft was harvested. None of the patients showed any untoward allergic reaction.

Ideally, the first aim of repair should be achieving a successful occlusion of CSF leakage with minimal morbidity, without significant prolongation of operative and hospitalization time and without compromise of the quality of post-operative magnetic resonance imaging (40).

Fibrin sealants are being used in surgery both as a supplement to sutures and as an assurance for providing optimal wound integrity when sutures are insufficient or would aggravate bleeding. Although their primary utilization is to achieve haemostassis, they can also seal air and body fluid leakages and therefore used as a glue and as a matrix for local drug delivery. Fibrin sealants mimic the final stages of the clotting cascade, but because being independent of the body's self clotting mechanism, they are also effective in coagulopathies or patients under heparin or anticoagulant therapy (3).

There are numerous fibrin sealants in using skull base reconstruction and AFS is a new one. AFS is prepared by the fully automated Vivostat system from patient's own blood. Compared to other sealant products, AFS offers a multitude of benefits to both the patient and the surgeon.

AFS was applied with the use of Vivostat ${ }^{\circ}$ System. In this system the entire process, from taking the patient's own blood sample until the sealant was ready to use is fully automatic and controlled, which both provides an ease to use for the surgeon and reduces the risk of contamination and antigenic reactivity.

AFS (Vivostat ${ }^{\circ}$ ) demonstrates excellent biocompatibility. Conventional products are most often based on either single or pooled donor blood or includes bovine components. Unlike these products, AFS (Vivostat ${ }^{\circ}$ ) is autologous and that nature makes it free for any exogenous thrombin or bovine components, which also efficiently eliminates the risks of bovine or human borne contaminants. This is the only way to protect the patient against unidentified pathogen transmissions. In addition, clinical studies and comparative tests have demonstrated that AFS (Vivostat ${ }^{\circ}$ ) is superior to conventional fibrin sealants on haemostasis time, elasticity, tissue adhesion and tissue impact (25).

The application devices of AFS (Vivostat ${ }^{\circ}$ ) System are designed to deliver the sealant in a precise and targeted manner with minimum waste. During the entire surgical procedure AFS can be used intermittently without occlusion, which is common in conventional systems. The wide selection of these application devices provides the surgeon a freedom in the use of the fibrin sealant. Furthermore, AFS can be used at a very close space that allows pinpoint application and rapid polymerisation ensures that the fibrin remains where it is applied. When the Vivostat ${ }^{\circ}$ Solution polymerizes, it turns into a white "gel" that is visible to the eye, which helps the surgeon to see to which area the solution has been applied. A $33 \mathrm{~cm}$ stick-like Vivostat endoscopic applicator is used in EETS. The single use endoscopic application catheter is easily loaded in to the endoscopic handle, which is inserted via a $5 \mathrm{~mm}$ trocar. The pre-bent spray tip enables the surgeon to manipulate the tip and spray in the multiple directions.

We used AFS (Vivostat ${ }^{\circ}$ ) in every stage of multilayer reconstruction technique to prevent CSF leak with large skull base defects following EETS. Postoperative CSF leak was determined in 2 patients (3.6\%). The significant advantage of AFS was that being controlled amount and speed of application by surgeon. This allows to easy application for surgeons whenever they want. Therefore any amount of AFS can be used in every stage of multilayer reconstruction. Stick-like applicator for specially made endonasal surgery is other advantage of this system. It is long enough and has great finesse with an easy to use for endoscopic endonasal 
approach. In addition, using AFS does not affect quality of post-operative magnetic resonance imaging. In this study, there were no complications associated with the use of AFS (Vivostat ${ }^{\circ}$.

\section{CONCLUSIONS}

The endoscopic endonasal transsphenoidal surgery is a minimally invasive procedure for the treatment of pituitary and same of scull base lesions. For a successful surgery and in order to prevent the CSF leak and related complications, skull base reconstruction is an important step of EETS, particularly in extended surgery. Because of advantages, using of AFS combined with multilayer reconstruction technique is a safe and effective method to prevent CSF leak in large defects following EETS.

\section{REFERENCES}

1. Arita K, Kurisu K, Tominaga A: Size-adjustable titanium plate for reconstruction of the sella turcica. Technical note. J Neurosurgery 91(6):1055-1057, 1999

2. Belboul A, Dernevik L, Aljassim O, Skrbic B, Radberg G, Roberts D: The effect of autologous fibrin sealant (Vivostat) on morbidity after pulmonary lobectomy: A prospective randomised, blinded study. European Journal of Cardiothoracic Surgery 26(6):1187-1191, 2004

3. Bpharm RT, Beierlein W, Debrix I: Evaluating the differences between fibrin sealants: Recommendations from an international advisory panel of hospital pharmacists. EJHP Science 12(1):3-9, 2006

4. Cappabianca P, Cavallo LM, Valente V: Sellar repair with fibrin sealant and collagen fleece after endoscopic endonasal transsphenoidal surgery. Surgical Neurology 62(3):227-233, 2004

5. Cappabianca P, Cavallo LM, Mariniello G, de Divitiis O, Romero $A D$, de Divitiis E: Easy sellar reconstruction in endoscopic endonasal transsphenoidal surgery with polyester-silicone dural substitute and fibrin glue: Technical note. Neurosurgery 49(2):473-476, 2001

6. Cappabianca P, Cavallo LM, Esposito F, Valente V, De Divitiis E: Sellar repair in endoscopic endonasal transsphenoidal surgery: Results of 170 cases. J Neurosurgery 51(6): 1362-1371, 2002

7. Cavallo LM, Messina A, Esposito F, Divitiis O, Fabbro MD, Divitiis E, Cappabianca P: Skull base reconstruction in the extended endoscopic transsphenoidal approach for suprasellar lesions. J Neurosurgery 107: 713-720, 2007

8. Couldwell WT, Weiss MH, Rabb C, Liu JK, Apfelbaum RI, Fukushima T: Variations on the standard transsphenoidal approach to the sellar region with emphasis on the extended approaches and parasellar approaches: Surgical experience in 105 cases. J Neurosurgery 55: 539-550, 2004

9. Costantino PD, Hiltzik DH, Sen C: Sphenoethmoid cerebrospinal fluid leak repair with hydroxyapatite cement. Archives of Otolaryngology--Head and Neck Surgery 127(5):588-593, 2001
10. Dusick JR, Mattozo CA, Esposito F, Kelly DF: BioGlue for prevention of postoperative cerebrospinal fluid leaks in transsphenoidal surgery: A case series. Surgical Neurology 66(4):371-376, 2006

11. Dusick JR, Esposito F, Kelly DF, Cohan P, DeSalles A, Becker DP: The extended direct endonasal transsphenoidal approach for nonadenomatous suprasellar tumors. J Neurosurg 102: 832-841, 2005

12. El-Banhawy OA, Halaka AN, El-Dien AE, Ayad H: Sellar floor reconstruction with nasal turbinate tissue after endoscopic endonasal transsphenoidal surgery for pituitary adenomas. Minimally Invasive Neurosurgery 46(5):289-292, 2003

13. Esposito F, Dusick JR, Fatemi N, Kelly DF: Graded repair of cranial base defects and cerebrospinal fluid leaks in transsphenoidal surgery. Neurosurgery 60(4 Suppl 2): 295-303, 2007

14. Gidaro S, Cindolo L, Lipsky K, Zigeuner R, Schips L: Efficacy and safety of the haemostasis achieved by Vivostat system during laparoscopic partial nephrectomy. Archivio italiano di urologia, andrologia: Organo ufficiale [di] Societa italiana di ecografia urologica e nefrologica. Associazione Ricerche in Urologia 81(4):223-227, 2009

15. Hadad G, Bassagasteguy L, Carrau RL: A novel reconstructive technique after endoscopic expanded endonasal approaches: Vascular pedicle nasoseptal flap. Laryngoscope 116(10): 1882-1886, 2006

16. Han ZL, He DS, Mao ZG, Wang HJ: Cerebrospinal fluid rhinorrhea following trans-sphenoidal pituitary macroadenoma surgery: Experience from 592 patients. Clinical Neurology and Neurosurgery 110(6):570-579, 2008

17. Ismail AS, Costantino PD, Sen C: Transnasal transsphenoidal endoscopic repair of CSF leakage using multilayer acellular dermis. Skull Base 17(2):125-132, 2007

18. Jane JA Jr, Thapar K, Kaptain GJ, Maartens N, Laws ER: Pituitary surgery: Transsphenoidal approach. Neurosurgery 51(2): 435-442, 2002

19. Kaptain GJ, Vincent DA, Laws ER: Cranial base reconstruction after transsphenoidal surgery with bioabsorbable implants. J Neurosurgery 48(1):232-234, 2001

20. Kaptain GJ, Vincent DA, Sheehan JP, Laws ER:Transsphenoidal approaches for the extracapsular resection of midline suprasellar and anterior cranial base lesions. J Neurosurgery 49: 94-101, 2001

21. Kassam A, Carrau RL, Snyderman CH, Gardner P, Mintz AJ: Evolution of reconstructive techniques following endoscopic expanded endonasal approaches. Neurosurgical focus 19(1):E8, 2005

22. Kassam AB, Thomas A, Carrau RL: Endoscopic reconstruction of the cranial base using a pedicled nasoseptal flap. Neurosurgery 63(1 Suppl 1):44-52, 2008

23. Kelly DF, Oskouian RJ, Fineman I: Collagen sponge repair of small cerebrospinal fluid leaks obviates tissue grafts and cerebrospinal fluid diversion after pituitary surgery. Neurosurgery 49(4):885-890, 2001 
24. Kjaergard HK, Trumbull HR: Vivostat system autologous fibrin sealant: Preliminary study in elective coronary bypass grafting. Annals of Thoracic Surgery 66(2):482-486, 1998

25. Kjaergard HK, Velada JL, Pedersen JH, Fleron H, Hollingsbee DA: Comparative kinetics of polymerisation of three fibrin sealants and influence on timing of tissue adhesion. Thrombosis Research 98(2):221-228, 2000

26. Kjaergard HK, Trumbull HR: Vivostat system autologous fibrin sealant: Preliminary study in elective coronary bypass grafting. Ann Thorac Surgery 66: 482-486, 1998

27. Kubo S, Inui T, Hasegawa H, Yoshimine T: Repair of intractable cerebrospinal fluid rhinorrhea with mucosal flaps and recombinant human basic fibroblast growth factor: Technical case report. Neurosurgery 56(3):E627, 2005

28. Kumar A, Maartens NF, Kaye AH: Reconstruction of the sellar floor using Bioglue following transsphenoidal procedures. Journal of Clinical Neuroscience 10(1):92-95, 2003

29. Locatelli D, Vitali M, Custodi VM, Scagnelli P, Castelnuovo P, Canevari FR: Endonasal approaches to the sellar and parasellar regions: Closure techniques using biomaterials. Acta Neurochirurgica 151(11):1431-1437, 2009

30. Locatelli D, Vitali M, Custodi VM, Scagnelli $P$, Castelnuovo P, Canevari FR: Endonasal approaches to the sellar and parasellar regions: Closure techniques using biomaterials. Acta Neurochir 151:1431-1437, 2009

31. Nishioka H, Izawa H, Ikeda Y, Namatame H, Fukami S, Haraoka J: Dural suturing for repair of cerebrospinal fluid leak in transnasal transsphenoidal surgery. Acta Neurochirurgica 151(11):1427-1430, 2009

32. Schips L, Dalpiaz O, Cestari A: Autologous fibrin glue using the Vivostat system for hemostasis in laparoscopic partial nephrectomy. European Urology 50(4):801-805, 2006

33. Sciarretta V, Mazzatenta D, Ciarpaglini R, Pasquini E, Farneti G, Frank G: Surgical repair of persisting CSF leaks following standard or extended endoscopic transsphenoidal surgery for pituitary tumor. Minimally Invasive Neurosurgery 53(2): 55-59, 2010
34. Seiler RW, Mariani L: Sellar reconstruction with resorbable vicryl patches, gelatin foam, and fibrin glue in transsphenoidal surgery: A 10-year experience with 376 patients. J Neurosurgery 93(5):762-765, 2000

35. Shapiro SA, Scully T: Closed continuous drainage of cerebrospinal fluid via a lumbar subarachnoid catheter for treatment or prevention of cranial/spinal cerebrospinal fluid fistula. J Neurosurgery 30(2):241-245, 1992

36. Tabaee A, Anand VK, Brown SM, Lin JW, Schwartz TH: Algorithm for reconstruction after endoscopic pituitary and skull base surgery. Laryngoscope 117(7):1133-1137, 2007

37. Tataranu L, Gorgan MR, Ciubotaru V: Endoscopic endonasal transsphenoidal approach in the management of sellar and parasellar lesions: Indications and standard surgical technique (Part I). Romanian Neurosurgery 17(1):52-63, 2010

38. Van Aken MO, Feelders RA, de Marie S: Cerebrospinal fluid leakage during transsphenoidal surgery: Postoperative external lumbar drainage reduces the risk for meningitis. Pituitary 7(2):89-93, 2004

39. Van Velthoven V, Clarici G, Auer LM: Fibrin tissue adhesive sealant for the prevention of CSF leakage following transsphenoidal microsurgery. Acta Neurochirurgica 109 (1-2):26-29, 1991

40. Wang YY, Kearney T, Gnanalingham KK: Low-grade CSF leaks in endoscopic trans-sphenoidal pituitary surgery: Efficacy of a simple and fully synthetic repair with a hydrogel sealant. Acta Neurochirurgica 153(4):815-822, 2011

41. Yano S, Tsuiki $H$, Kudo M: Sellar repair with resorbable polyglactin acid sheet and fibrin glue in endoscopic endonasal transsphenoidal surgery. Surgical Neurology 67(1):59-64, 2007 